JPDS (Oktober, 2019), Vol. 2, No. 2 h.47-53

E-ISSN: 2655-2469

(C) 2019 Penulis

\title{
MENCIPTAKAN PEREMPUAN CERDAS BERINTERNET MELALUI PENANAMAN LITERASI DIGITAL KOMUNITAS 'RUANG BERKARYA PEREMPUAN'
}

\author{
Ananda Dwitha Yuniar*, Alan Sigit Fibrianto, Rani Prita Prabawangi, Kun Sila Ananda \\ Ananda.dwitha.fis@um.ac.id \\ Prodi Pendidikan Sosiologi, Fakultas Ilmu Sosial, Universitas Negeri Malang \\ Diterima 10 Oktober 2018, dipublikasikan 31 Oktober 2019
}

\begin{abstract}
Abstrak
Berbagai fitur menarik yang ditawarkan oleh gadget smartphone telah menyebabkan ketergantungan dalam kehidupan sehari-hari mulai generasi orang tua hingga balita. Ketergantungan akan pemakaian smartphone juga tidak terlepas dari akses penggunaan internet yang semakin mudah. Pertumbuhan internet begitu banyak membawa pengaruh positif seperti banyaknya terserap tenaga kerja, media aktualisasi diri, dan kemudahan akses informasi. Namun, pertumbuhan internet juga tak dapat dilepaskan dari pengaruh negatif antara lain hoaks yang terdiri dari misinformasi, malinformasi, dan disinformasi. Selain itu, orangtua khususnya ibu memiliki peran yang fundamental dalam menavigasi segala tantangan yang disajikan oleh teknologi internet. Penggunaannya menjadi candu bagi balita, hingga banyak menimbulkan kekhawatiran orangtua akan berpengaruh terhadap daya tumbuh kembang anak. Melalui program literasi digital diharapkan akan menciptakan ibu-ibu cerdas untuk generasi anak selanjutnya.
\end{abstract}

Kata Kunci: literasi digital, perempuan, hoaks, pengasuhan era digital

\section{PENDAHULUAN}

Ketergantungan akan berbagai fitur yang ditawarkan oleh teknologi internet telah melekat dalam kehidupan sehari-hari, tidak hanya pada generasi muda tetapi juga generasi orang tua. Hal ini disebabkan karena kepraktisan dan kecepatan bagi setiap orang yang menggunaannya. Pertumbuhan teknologi internet yang begitu pesat di Indonesia turut merubah perilaku masyarakat. Internet dengan berbagai macam platform seperti media sosial telah menjelma dan melekat dalam keseharian masyarakat informasi. Pertumbuhan internet begitu banyak membawa pengaruh positif seperti banyaknya terserap tenaga kerja, media aktualisasi diri, dan kemudahan akses informasi. Namun, pertumbuhan internet juga tak dapat dilepaskan dari pengaruh negatif.

Pertama, derasnya arus informasi melalui internet menyebabkan sulitnya menyaring informasi atau berita faktual dan berita palsu (hoaks). Hal ini kemudian memicu hoaks mudah tersebar jika masyarakat tidak memiliki kapasitas dan pengetahuan dalam menggunakan media sosial. Seperti berita hoax yang memunculkan reaksi public baru-baru ini ketika Menteri Keuangan Sri Mulyani Indrawati dituding akan menjual Pulau Bali guna membayar hutang Negara (Tempo, 2018). Berita yang tidak berdasar ini tersebar melalui akun Facebook dan begitu banyak orang 'menelan mentah' kabar tersebut. Masyarakat mudah terprovokasi jika itu berkaitan dengan kinerja pemerintahan. Berita ini semakin meredup ketika Sri Mulyani berkenan mengklarifikasi kebenarannya.

Perempuan adalah kelompok yang paling rentan terpapar hoaks. Bukan hanya sebagai korban, perempuan juga berperan sebagai kelompok yang paling banyak menyebarkan hoaks. Catatan Mabes Polri mengungkap bahwa dalam kurun waktu 31 Oktober - 8 November 2016, secara spesifik ibu rumah tangga (usia 20 - 42 tahun) mendominasi sebagai tersangka penyebar hoaks (Jawa Pos, 2018). Selain itu, banyaknya hoaks dengan tema kesehatan, pendidikan, dan kejadian sosial membuat perempuan rentan menjadi korban hoaks. Penyebaran hoaks yang dilakukan ibu-ibu biasanya merupakan hoaks 
misinformasi. Artinya, ibu-ibu menyebarkan informasi yang tidak benar tanpa ada intensi menyebarkan kebohongan.

Hoaks sering kali tersebar melalui media sosial seperti jejaring pertemanan terbesar seperti facebook hingga aplikasi pesan sepert Whatsapp. Hal negatif akhirnya cepat beredar melampaui jaringan internet hingga menimbulkan kepanikan. Ironisnya, berdasarkan pemeriksaan Mabes Polri, penyebar hoaks penculikan anak didominasi lbu rumah tangga (Jawa Pos, 2018). Belum lagi kesenjangan pemanfaatan internet oleh perempuan. Menurut Womenwill (2018), 52 persen perempuan Indonesia merasa kesulitan melakukan pencarian di internet. Isu disinformasi dalam pusaran hoaks memang menjadi salah satu aspek literasi yang dianggap penting. Memang banyak hoaks politik, agama, dan kesehatan yang beredar dalam lingkar ibu-ibu. Contoh sederhana saja, banyak dari generasi muda yang mengaku bahwa hoaks sering dikirimkan melalui grup keluarga.

Kedua, pengaruh negatif dalam media baru yang mewadahi dan memfasilitasi audience untuk menyampaikan feedback secara langsung memicu adanya cyberbullying dan hatespeech. Kebebasan bercara dan partisipasi public sering disalah artikan oleh orang-orang tidak bertanggungjawab untuk memulai perpecahan. Hatespeech memiliki beragam pengertian, menurut Waldron (2012) hatespeech kebebasan untuk mengungkapkan kebencian dalam diri. Sedangkan menurut Gelber (2002) hatespeech merupakan ekspresi yang ditunjukkan seseorang untuk mengintimidasi dan merendahkan orang lain. Indonesia juga telah mengatur ujaran kebencian dalam Undang-undang ITE pasal 28 ayat 2:

"Setiap orang dengan sengaja dan tanpa hak menyebarkan informasi yang ditujukan untuk menimbulkan rasa kebencian atau permusuhan individu dan/atau kelompok masyarakat tertentu berdasarkan atas suku, agama, ras, dan antargolongan (SARA)."

Hal ini menjelaskan bahwa ujaran kebencian merupakan hal yang dapat mengancam orang lain sehingga tidak sepantasnya dilakukan. Namun kebebasan dalam bermedia sosial di Indonesia tidak dapat dilepaskan dari adanya perilaku hatespeech, termasuk di dalamnya cyberbullying. Beberapa waktu lalu Ahmad Dhani seorang musisi Indonesia dijadikan tersangka karena terjerat kasus ujaran kebencian tentang penistaan agama melalui twitter. Selain itu beberapa waktu lalu terjadi perundungan atau persekusi terhadap seorang jurnalis majalah olahraga karena postingan twitter tentang penceramah Abdul Somad. Tidak hanya kecaman di dunia siber, perundungan juga terjadi berlanjut di dunia nyata. Akibat intimidasi ini, jurnalis tersebut harus kehilangan pekerjaannya.

Berdasarkan fakta dan kondisi empiris di Indonesia yang telah disebut di atas, beberapa kejadian tidak menyenangkan dipicu oleh ketidakbijakan/ kesenjangan literasi dalam penggunaan media sosial. Dengan demikian, sebagai akademisi yang memiliki latarbelakang berbagai keilmuan yang relevan, kami berharap dapat menginisiasi dan membentuk peer-group agar program pemberdayaan masyarakat etika bermedia sosial ini dapat disosialisasikan, disebarkan dan dapat berkelanjutan dalam jangka panjang. Selain itu, kejadian-kejadian yang tidak bertanggungjawab dapat diminimalisir dengan melakukan literasi digital kepada ibu -ibu yang kerap kali terjebak dalam jurang hoaks. Kelompok ibu-ibu nampaknya tidak dianggap dalam narasi besar perkembangan teknologi negara kita. Mereka kerap dituduh gaptek dan disalahkan sebagai penyebar hoaks, padahal ini terjadi karena kelompok ibu yang terabaikan berada dalam jurang literasi digital yang perlu dimulai untuk ditanamkan. Batasan masalah pada pengabdian masyarakat ini adalah: (1) Bagaimana upaya yang dapat dilakukan untuk memberikan literasi kepada perempuan dalam menyebarkan konten positif melalui internet?; (2) Bagaimana upaya yang dapat dilakukan untuk menanggulangi ancaman potensi bahaya terbesar yang sedang dihadapi oleh Indonesia, yaitu penyebaran konten negatif melalui internet seperti hoax? 


\section{METODE}

Berdasarkan serangkaian permasalahan utama, solusi yang ditawarkan melalui pengabdian kepada masyarakat ini yaitu dibuatnya "Literasi Digital untuk Perempuan". Hal ini dirasa merupakan kegiatan yang paling tepat untuk membantu masyarakat menyelesaikan permasalahan yang cukup kompleks berkaitan dengan pemanfaatan teknologi, khususnya dalam penggunaan media sosial yang fenomenanya sedang marak saat ini di berbagai kalangan. Melalui kegiatan yang bertumpu pada pengetahuan akan etika bermedia sosial, diharapkan dapat membuat masyarakat dari berbagai kalangan pengguna media sosial untuk berperilaku sesuai dengan batas-batas tertentu seperti yang ditawarkan dalam pengabdian ini. Sehingga masyarakat khususnya ibu-ibu yang kerap dinilai terjebak dalam pusaran hoaks tidak secara mentah (tanpa arah) memanfaatkan serta menggunakan media sosial, akan tetapi mampu secara matang (mengerti akan etika bermedia sosial) dalam memanfaatkan serta menggunakan media sosial dalam kesehariannya.

Kondisi yang demikan menjadikan gerakan literasi media sosial media yang menjadikan warga net sebagai pengguna yang cerdas menjadi cara yang dirasa paling efektif dan penting dilakukan. Melalui literasi sosial media, pengguna akan dididik menjadi pengguna internet yang baik dan cerdas, bukan hanya akan mampu membedakan konten yang benar dan salah, baik dan buruk, namun juga mencegahnya menjadi produktor konten negatif, dan pemutus rantai penyebaran konten negatif dengan tidak menyebar ulang sebuah konten dan berinisiatif untuk melaporkan serta mengedukasi sekitarnya mengenai bahaya konten tersebut. Untuk mencapai tujuan tersebut, literasi media yang dilakukan akan memfokuskan muatannya pada aspek hukum, aspek psikologis, dan etika.

\begin{tabular}{llll}
\hline NO & Topik & & \multicolumn{1}{c}{ Muatan } \\
\hline $\mathbf{1}$ & Hukum & - & Definisi dan contoh jenis-jenis konten negatif di sosial media \\
& & - & Sebab-sebab munculnya konten negatif \\
& & - & Ancaman hukuman bagi pengunggah maupun penyebar pesan \\
\hline $\mathbf{2}$ & Sosial & - & Memahami faktor psikis produktor maupun penyebar pesan \\
& dan & - & Memahami dampak sosial dan psikis dari konten negatif terhadap penerima \\
& Psikologi & & pesan dan masyarakat secara luas \\
\hline $\mathbf{3}$ & Etika & - & Langkah-langkah untuk membedakan informasi yang benar dan salah \\
& & - & Apa yang harus dilakukan warga net saat menemukan konten negatif \\
& & - & Etika bermedia sosial \\
\hline
\end{tabular}

Tabel 1. Indikator Literasi Media Sosial

Meski unit target sasaran terkecil dari gerakan ini adalah individu, namun sesungguhnya literasi sosial media yang akan kami lakukan ini adalah gerakan yang menggunakan pendekatan ganda, yakni individu dan sosial sekaligus. Jika pendekatan individu memperhatikan faktor biologis dan psikologis yang mempengaruhi perilaku seseorang, maka pendekatan sosial membahas aspek-aspek kebudayaan manusia seperti keluarga, tradisi, adat istiadat, norma sosial, dan lain sebagainya. Dapat dikatakan pendekatan sosial melihat lingkungan atau aspek di luar individu sebagai factor yang mempengaruhi sikap dan perilakunya. Mengapa seseorang memproduksi, mempercayai, dan atau menyebarkan konten negatif tidak dipungkiri dipengaruhi oleh faktor-faktor yang sifatnya internal dan eksternal. Oleh karenanya, dalam merancang gerakan literasi sosial media ini, pendekatan tersebut menjadi pertimbangan dalam menetapkan sasaran, tujuan, hingga media dan muatan literasi.

Literasi yang dilakukan tidak hanya mengajak warga net lebih hati-hati menyikapi informasi yang tersebar di internet, namun juga memikirkan dampak psikologis dari penyebaran konten negatif terhadap bukan saja objek berita namun pembacanya. Sebagai contoh adalah penyebaran gambar korban ledakan bom dari aksi terorisme, warga net perlu disadarkan bahwa gambar tersebut tidak hanya membantu memperlancar ketercapaian tujuan para teroris untuk menyebarkan anacaman namun juga dapat melukai 
perasaan keluarga korban, serta menimbulkan dampak psikologis (paranoid, trauma) terhadap penerima pesan yang melihat gambar tersebut.

Gerakan literasi sosial media juga akan mengajak warga net menyadari bahwa dalam dunia digital, meski terisolasi sesungguhnya diri mereka terhubung dalam sebuah jejaring yang luas. Karena itu kesadaran solidaritas sosial menjadi penting, bahwa dalam jaringan garis batas aksi individu dan kolektif sangatlah sulit dibedakan, bahwa aksi kecil mereka, satu klik, akan memberikan dampak terhadap viralitas yang luas sebuah konten negatif. Gerakan literasi sosial media ini memperhitungkan aspek demografis pengguna internet yang bukan hanya kalangan remaja dan dewasa muda yang sebagian besar berperan sebagai pelajar, mahasiswa atau pekerja namun juga warga senior dan ibu rumah tangga. Melihat individuindividu tersebut bukan hanya sebagai perseorangan, namun juga bagian dari komunitas, karena itu pelaksanaan literasi media sosial secara offline akan menyasar pada komunitas atau perkumpulan.

\section{HASIL DAN PEMBAHASAN}



'Ruang berkarya perempuan' merupakan sebuah komunitas di kota Pasuruan yang terdiri dari individu yang memiliki minat dan bakat. Komunitas ini bertujuan untuk berbagi dan berekspresi atas potensi yang dimiliki dalam mengisi waktu luang mereka selain sebagai ibu rumah tangga. Mereka memiliki misi yang sama, bahwa tugas ibu rumah tangga bukan hanya mengurus anak, tetapi juga mengembangkan potensi diri. Potensi yang mereka miliki antara lain menjadi penjual belanja daring, penulis buku atau cerpen, merajut, menjahit, dan lain sebagainya. Saat ini jumlah anggota aktif komunitas Ruang berkarya perempuan' berjumlah kurang lebih 35, yang tergabung dari berbagai wilayah kabupaten Malang, Pandaan, Pasuruan, dan Gempol. Komunitas ini didirikan oleh Bunda Andita Aryoko, perempuan yang aktif mengasah diri dengan menulis buku dan memublikasikannya. Kegiatan pengabdian masyarakat dilakukan selama dua hari dengan total peserta kurang lebih 30 orang, hari pertama diisi dengan brainstorming dan observasi, hari kedua diisi dengan pembekalan dan sosialisasi materi-materi terkait yang ibu-ibu dalam komunitas. Materi dibagi ke dalam dua sub bagian yakni materi besar pertama Materi lbu Literat Kebal Hoaks dan Pengasuhan di Era Digital (Digital Parenting).

\section{Perempuan dan Hoaks}

Hasil survei Mastel (2017) mengemukakan bahwa saluran hoaks terbesar adalah lewat media sosial dan aplikasi chatting. Sekitar $92,40 \%$ hoaks disebarkan lewat media sosial seperti Facebook, Twitter, 


\section{Menciptakan Perempuan Cerdas Berinternet melalui Penanaman Literasi Digital Komunitas 'Ruang Berkarya Perempuan'}

Instagram, dan Path. Sementara 62,80\% hoaks menyebar lewat aplikasi chatting seperti Whatsapp, Line, dan Telegram. Sementara itu, perempuan adalah kelompok yang paling rentan terpapar hoaks. Bukan hanya sebagai korban, perempuan juga berperan sebagai kelompok yang paling banyak menyebarkan hoaks. Catatan Mabes Polri mengungkap bahwa dalam kurun waktu 31 Oktober - 8 November 2016, ibu rumah tangga (usia 20-42 tahun) mendominasi sebagai tersangka penyebar hoaks. Selain itu, banyaknya hoaks dengan tema kesehatan, pendidikan, dan kejadian sosial membuat perempuan rentan menjadi korban hoaks.

Penyebaran hoaks yang dilakukan ibu-ibu biasanya merupakan hoaks misinformasi. Artinya, ibuibu menyebarkan informasi yang tidak benar tanpa ada intensi menyebarkan kebohongan. Mengapa ibuibu banyak yang menyebarkan hoaks misinformasi dilatarbelakangi oleh kettidakpahaman tentang tata cara mengenal kredibilitas sumber media, tidak memiliki pemahanan definisi dan karakteristik hoaks, tidak mengetahui cara mengecek fakta, namun merasa perlu menyebarkan informasi demi kebaikan orang terdekat, dan tidak memahamin risiko penyebaran berita bohong melalui internet. Hal ini dapat disimpulkan bahwa perempuan yang terdiri dari ibu-ibu sering terjebak oleh hoaks karena kurangnya pengetahuan.

UNESCO membagi hoaks menjadi tiga jenis, yaitu, Hoaks berupa misinformasi. Misinformasi merupakan informasi yang tidak benar atau tidak akurat, namun orang yang menyebarkannya berkeyakinan bahwa informasi tersebut benar dan dapat dipercaya. Penyebar jenis hoaks ini biasanya tidak memiliki tujuan buruk, dan hanya ingin membagikan informasi. Hoaks berupa disinformasi. Disinformasi merupakan informasi yang tidak benar namun sengaja dibuat (direkayasa) untuk mempengaruhi masyarakat. Pihak yang membuat dan membagikan hoaks jenis ini biasanya memang bertujuan untuk membohongi masyarakat. Hoaks berupa malinformasi. Malinformasi merupakan informasi yang memilliki unsur kebenaran, baik berdasarkan potongan atau keseluruhan fakta objektif. Namun informasi ini disebarkan dengan tujuan merugikan pihak lain dan bukan didasarkan pada kepentingan publik. Hoaks jenis ini biasanya disertai dengan ujaran kebencian, diskriminasi, pelecehan, atau penyebaran data pribadi.

lbu-ibu yang tergabung dalam komunitas ruang berkarya perempuan cenderung membaca judul cerita atau paragraf pembuka. Sehingga mereka tidak membaca informasi yang disampaikan secara utuh, mudah mengambil kesimpulan, dan terpancing untuk menyebarluaskan. Hoaks biasanya dibuat untuk menyulut emosi, sehingga ibu-ibu kadang lupa berpikir logis dan kritis. Bagi sebagian ibu mereka juga sering menemui tentang informasi yang belum jelas kebenarannya. Melalui hal ini kami sebagai akademisi memberikan saran untuk mengingatkan secara pribadi dan menyebarkan gerakan berantas hoaks.

\section{Pengasuhan di Era Digital}

Perkembangan teknologi informasi dan komunikasi merupakan hal yang banyak mendapat apresiasi bagi sebagian besar orang tua (Wong, 2010). Kehadiran ponsel pintar, laptop, tablet, dan koneksi internet dinilai telah membuat hidup menjadi lebih mudah dan murah. Sebagai contoh, dengan smartphone tidak perlu lagi membeli buku resep, karena tersedia berbagai resep yang dibagikan secara gratis bahkan oleh para chef ternama. Selain itu, pengguna dapat dengan mudah menghubungi orang tua di kampung halaman atau bahkan guru anak-anak di sekolah. Tidak hanya orang tua, internet juga menyediakan berbagai aplikasi yang dapat membantu anak belajar. Mulai dari belajar mengenali warna, berhitung, bernyanyi, hingga mencari data untuk menyelesaikan tugas di sekolah. Teknologi adalah hal yang sudah menjadi bagian hidup kita sehari-hari, Namun akhir-akhir ini banyak kekhawatiran terhadap pengaruh gadget terhadap perkembangan anak (Tynes, 2007).

Berbagai studi telah dilakukan untuk menemukan kaitan lama penggunaan gadget (screen time) dengan kesejahteraan psikologis (psychological well being). Beberapa penelitian menemukanadanya hubungan antara screen time dengan rendahnya kesejahteraan psikologis seseorang (Khurana et al., 2015; Twenge \& Campbell, 2018) sementara studi lainnya tidak menemukan adanya pengaruh lama penggunaan gadget terhadap tumbuh kembang seseorang anak (Granic et al., 2014; Odgers, 2018). Carol 
Ryff menyusun konsep kesejahteraan psikologis bukan hanya sekedar 'bahagia', melainkan ketika tujuan hidup seseorang bukan hanya sekedar bahagia, melainkan hidup dengan moralitas yang baik. Untuk mencapainya, menurut (Ryff, 2014) ada beberapa faktor yang berpengaruh yakni Penerimaan diri (selfacceptance), Perkembangan diri (personal growth), Tujuan hidup (purpose in life), Penguasaan lingkungan (environmental mastery), Otonomi (autonomy), Hubungan baik dengan orang lain (positive relations with others).

Agar anak tumbuh menjadi individu dengan kesejahteraan psikologis yang baik, maka tugas kita adalah memastikan fisik dan emosinya berkembang sesuai dengan tahapannya. Erikson memperkenalkan 5 tahapan pertumbuhan emosi anak-anak.

\begin{tabular}{cl}
\hline Fase & \multicolumn{1}{c}{ Karakteristik Emosi } \\
\hline $\begin{array}{c}\text { Bayi } \\
(0-2 \text { tahun })\end{array}$ & $\begin{array}{l}\text { Anak belajar mempercayai orang lain. Anak yang merasa } \\
\text { diabaikan pada tahapan ini berpotensi memiliki kesulitan } \\
\text { membangun relasi dengan orang lain. }\end{array}$ \\
\hline $\begin{array}{c}\text { Kanak-kanak awal } \\
(2-3 \text { tahun })\end{array}$ & $\begin{array}{l}\text { Anak mulai belajar mandiri, malu, dan ragu-ragu. Hal ini } \\
\text { berkaitan dengan perkembangan kemampuan fisiknya. Di } \\
\text { mana keberhasilan melakukan sesuatu dan respon sekitarnya } \\
\text { akan berpengauh terhadap kemandiriannya. }\end{array}$ \\
\hline $\begin{array}{c}\text { Pra sekolah } \\
(3-5 \text { tahun })\end{array}$ & Anak mulai memiliki tujuan dan rasa bersalah. \\
Sekolah & $\begin{array}{l}\text { Emosi yang dominan pada tahapan ini adalah percaya diri dan } \\
\text { rendah diri, akibat interaksi dan sistem pendidikan. }\end{array}$ \\
\hline Remaja -11 tahun $)$ & $\begin{array}{l}\text { Hubungan dengan orang lain menjadi aspek penting pada } \\
\text { tahapan ini, sehingga pergulatan yang utama bagi remaja } \\
\text { adalah ingin diterima agar tidak merasa kesepian. }\end{array}$
\end{tabular}

Tabel 2. Tahap Perkembangan Psikososial

\section{Gadget dan Perkembangan Anak}

Menurut M Sundus, (2017) gadget tidak selalu berdampak negatif. Gadget dapat meningkatkatkan kemampuan motorik yang berkaitan dengan gerakan sederhana. Penggunaan gadget juga meminimalisir kekhawatiran orang tua akan cedera dan luka ynag mungkin dialami jika anak beraktivitas fisik di luar. Gadget juga meningkatkan kemampuan kognisi. Penggunaan aplikasi edukasi interaktif mampu meningkatkan kemampuan anak dalam memproses informasi, membangun argumen, mengingat dan menghungkan satu objek dengan lainnya.

Selain itu dengan memainkan video game, kemampuan kompetisi anak akan terasah. Ketika bermain game dengan saudara atau temannya, anak akan merasakan atmosfer kompetisi yang akan mengasah kemampuan mereka dalam menghadapi lingkungan yang kompetitif. Selain itu, M Sundus (2017) juga menyatakan bahwa gadget juga membuat anak asyik bermain sehingga memberikan waktu luang bagi orang tua untuk beristirahat atau menyelesaikan pekerjaannya. Meski demikian, ada hal-hal yang perlu kita waspadai. Penggunaan gadget oleh anak-anak berpotensi menimbulkan hal-hal negatif, seperti penurunan Perkembangan Otak, paparan radiasi, Menurunkan Interaksi khususnya dapat menimbulkan speech atau language delay, Penurunan kualitas dan kuantitas tidur, berpotensi merusak kesehatan mata anak-anak saat besar nanti.

\section{KESIMPULAN}

Teknologi digital tentu tidak dapat dijauhkan begitu saja, namun bagaimana agar kita terhindar dari dampak buruknya ketika digunakan oleh Anak di bawah umur dengan memilih program-program yang berkualitas dan interaktif dan dilakukan pendampingan, menentukan batasan waktu penggunaan adget 
yang diperkenankan, serta menciptakan kebersamaan dengan keluarga tanpa penggunaan gadget, contohnya bersepakat untuk tidak menggunakan gadget saat makaan malam. Pada dasarnya, teknologi hadir untuk memudahkan kita asal digunakan untuk alasan dan cara yang tepat. Perangkat digital dapat memudahkan kita dalam mendidik anak karena visualisasinya yang menarik dan interaktif. Namun aturan utama yang perlu diingat adalah: "Jangan jadikan gadget sebagai pengganti orang tua atau baby sitter". Penggunaan gadget pada anak adalah agar proses belajar menjadi lebih menarik, bukan untuk menggantikan kehadiran orang tua atau membuat anak sibuk agar kita dapat melakukan kegiatan lain.

\section{DAFTAR PUSTAKA}

Gelber, K. 2002. Speaking back: the free speech versus hate speech debate. Amsterdam: Benjamins Publishing Company

Granic I., Lobel A., Engels R.E. 2014. The benefits of playing video games. American psychologist, 69:6678

Jawa Pos. 2018. Miris, Penyebar hoax mayoritas ibu-ibu (Mabel Polri tetapkan 16 Tersangka) Diakses dari: https://www.jawapos.com/hoax-atau-bukan/12/11/2018/miris-penyebar-hoax-mayoritas-ibuibu/

Khurana, A., Bleakley, A., Jordan, A. B., \& Romer, D. 2015. The Protective Effects of Parental Monitoring and Internet Restriction on Adolescents' Risk of Online Harassment. Journal of Youth and Adolescence, 44(5), 1039-1047. https://doi.org/10.1007/s10964-014-0242-4

M Sundus. 2017. The Impact of using Gadgets on Children. Journal of Depression and Anxiety, 07(01). https://doi.org/10.4172/2167-1044.1000296

Mastel. 2017. Hasil Survei Mastel Tentang Wabah Hoax Nasional. Diakses dari: https://mastel.id/hasilsurvey-wabah-hoax-nasional-2017/

Odgers C. 2018. Smartphones are bad for some teens, not all. Nature. 554:432-434.

Ryff, C. D. 2014. Psychological Well-Being Revisited: Advances in the Science and Practice of Eudaimonia. Psychotherapy and Psychosomatics, 83(1), 10-28. https://doi.org/10.1159/000353263

Tempo. 2018. Sri Mulyani Meradang Dituding Jual Pulau Bali untuk Bayar Utang. Diakses dari: https://bisnis.tempo.co/read/1116417/sri-mulyani-meradang-dituding-jual-pulau-bali-untuk-bayarutang

Twenge, J. M., \& Campbell, W. K. 2018. Associations between screen time and lower psychological wellbeing among children and adolescents: Evidence from a population-based study. Preventive Medicine Reports, 12, 271-283. https://doi.org/10.1016/j.pmedr.2018.10.003

Tynes, B. M. 2007. Internet Safety Gone Wild?: Sacrificing the Educational and Psychosocial Benefits of Online Social Environments. Journal of Adolescent Research, 22(6), 575-584. https://doi.org/10.1177/0743558407303979

Undang-Undang Informasi Dan Transaksi Elektronik Tahun 2016 Pasal 28 Ayat 2. Diakses dari: https://web.kominfo.go.id/sites/default/files/users/4761/UU\%2019\%20Tahun\%202016.pdf

Unesco. Jurnalisme, "Berita Palsu", \& Disinformasi Konteks Indonesia, Penerjemah: Wendratama. Diakses dari: http://www.unesco.or.id/publication/JurnalismeBeritaPalsuDisinformasiKonteksIndonesia.pdf

Waldron, J. 2012. The Harm in Hate Speech, 303. Cambridge: Harvard University Press

Wong, Y. C. 2010. Cyber-Parenting: Internet Benefits, Risks and Parenting Issues. Journal of Technology in Human Services, 28(4), 252-273. https://doi.org/10.1080/15228835.2011.562629

Womenwill. 2018. Persentase wanita Indonesia yang menggunakan internet sehari-hari. Diakses dari: https://www.womenwill.com/int//id/insights/indonesia/ 